\title{
多軸・多重連結車両の操舵時の横方向応答*
}

\author{
青木 章*1，丸茂喜高"1，景山一郎 ${ }^{* 2}$
}

\section{Directional Response of Multi-Articulated Vehicles with Multiple Axles to Steering Input}

\author{
Akira AOKI ${ }^{* 1}$, Yoshitaka MARUMO and Ichiro KAGEYAMA \\ ${ }^{*}$ College of Industrial Technology, Nihon University \\ 1-2-1 Izumi-cho, Narashino-shi, Chiba, 275-8575 Japan
}

Directional response and directional stability of vehicle combinations are main research topics in vehicle safety. This paper analyzes the steering sensitivity in lane-change maneuvers of multi-articulated vehicles with multiple axles using simplified mathematical models. It also calculates the frequency response, pole, and zero in the transfer functions of each variable for two types of tractor-double-trailer, a tractor-semitrailer and a truck-full-trailer having multiple axles. The following conclusions are drawn. (1) The steering sensitivity of multi-articulated vehicles with multiple axles in lane-change maneuvers is composed of steering sensitivity in steady-state turns and the parameters of lane-change maneuvers. (2) The effect of the number of trailer axles on the damping ratio of zero is larger than that of the other parameters for multiple axles. (3) A large steering angle is necessary to change running lanes for multi-articulated vehicles with multiple axles that have low steering sensitivity in lane-change maneuvers; therefore, the rise time is short. Moreover, if the vehicle combination has a low damping ratio of oscillatory modes, the settling time is long, and the overshoot and maximum deviation are large.

Key Words : Vibration of Moving Body, Transient Response, Coupled Vibration, Multi-Articulated Vehicle, Multiple Axles, Trailer, Directional Response, Lane Change Maneuver, Obstacle Avoidance, Stability Factor, Steering Sensitivity, Off-Tracking

\section{1. まえがき}

大型商業用の連結車両の横方向運動に関する研究課題の一つとして, 各車両の車軸の数と配置が方向安定性と 操舵時の横方向応答に及ぼす影響の検討がある. 前報 (1) では多軸のトラクタ・ダブルストレーラの方向安定性を 簡単化した数学モデルにより検討している. その結果, 多軸・多重連結車両の運動方程式が, 各車両の複数軸を 仮想軸として取り扱った運動方程式に幾つかの項を付加することにより簡略化できることを明らかにしている. また, 非振動安定性と定常円旋回時の操舵の感度を解析し, さらに操舵の感度と特性根に及ぼす複数軸の軸数お よび隣接軸間距離の影響を数值計算により明らかにしている.

さて, 多重連結車両に関する操舵時の横方向応答の研究は, 安全性からみて方向安定性のそれと共に重要な課 題である. 従来の多重連結車両の操舵入力に対する横方向応答に関する研究 (2)(3) では, 障害物回避操舵によって 最後尾のトレーラの横加速度が過大となり転覆に至るという観点から, 横加速度の最大值に着目している. これ に対して，障害物回避時などの多重連結車両の挙動として，他の車両や路外の構造物との接触およびそれによっ て誘発される事故の観点から，トラクタに対する各トレーラの追従性も重要となる.

一方, 従来検討が進んでいない, 多軸・多重連結車両の操舵時の基本的な横方向応答は, 開ループ系の伝達関 数から周波数応答および極・零点を求め, 多軸化の影響を明らかにすることが必要である.

* 原稿受付 2011 年 1 月 11 日

*1 正員, 日本大学生産工学部（广275-8575 千葉県習志野市泉町 1-2-1）

*2 正員, フェロー, 日本大学生産工学部

E-mail: aaoki@maple.ocn.ne.jp 
本研究では上記の基本的な横方向応答と中高速度の追従性に焦点をあて, 多軸・多重連結車両の簡単化した数 学モデルによる解析と数值計算をおこなっている.

以下第 2 章では，車両の横変位とヨー角を変数とした，多軸・多重連結車両に関する簡単化した路面固定座標 系の運動方程式について述べる. 第 3 章では, 多軸・多重連結車両の操舵入力に対する各変数の伝達関数と過渡 応答について定式化する．ここで，過渡応答の操舵様式として高速道路上を走行する場合に頻度の高い車線乗り 移り運動のそれを取り上げる. 第 4 章では，数值計算により，2 種類の多軸のトラクタ・ダブルストレーラにつ いて，まず，周波数応答および極・零点で多軸化の影響を検討する. 次に，車線乗り移り運動における追従性に ついて考察する．第 5 章では，本研究で得られた結論を述べる.

\section{2. 運 動 モ デル}

\section{$2 \cdot 1$ 仮定と省略}

本研究で横方向応答の検討のために用いる多軸・多重連結車両の運動モデルは, 図 1 に示寸路面固定右手下向 き直交座標系に関寸る簡単化した線形モデルである．記号を付録 1 に示す.

ここで，運動の自由度をトラクタの横すべり，トラクタのヨーイング，およびトラクタに対する各トレーラの 相対的なヨーイングとする. 取り扱う角 $\phi$ はいずれも微小であるため, $\sin \phi=\phi, \cos \phi=1$ とし, また各变数も微 小であるためそれらの積を省略する．なお，本モデルでは各車軸の左右輪の各 1 輪当りのコーナリングパワを合 計してその軸の車輪のコーナリングパワとして扱う．また，取り扱いを簡便化するために，トラクタ後軸および 各トレーラ軸における複数軸の隣接軸間距離を各々同じとする.

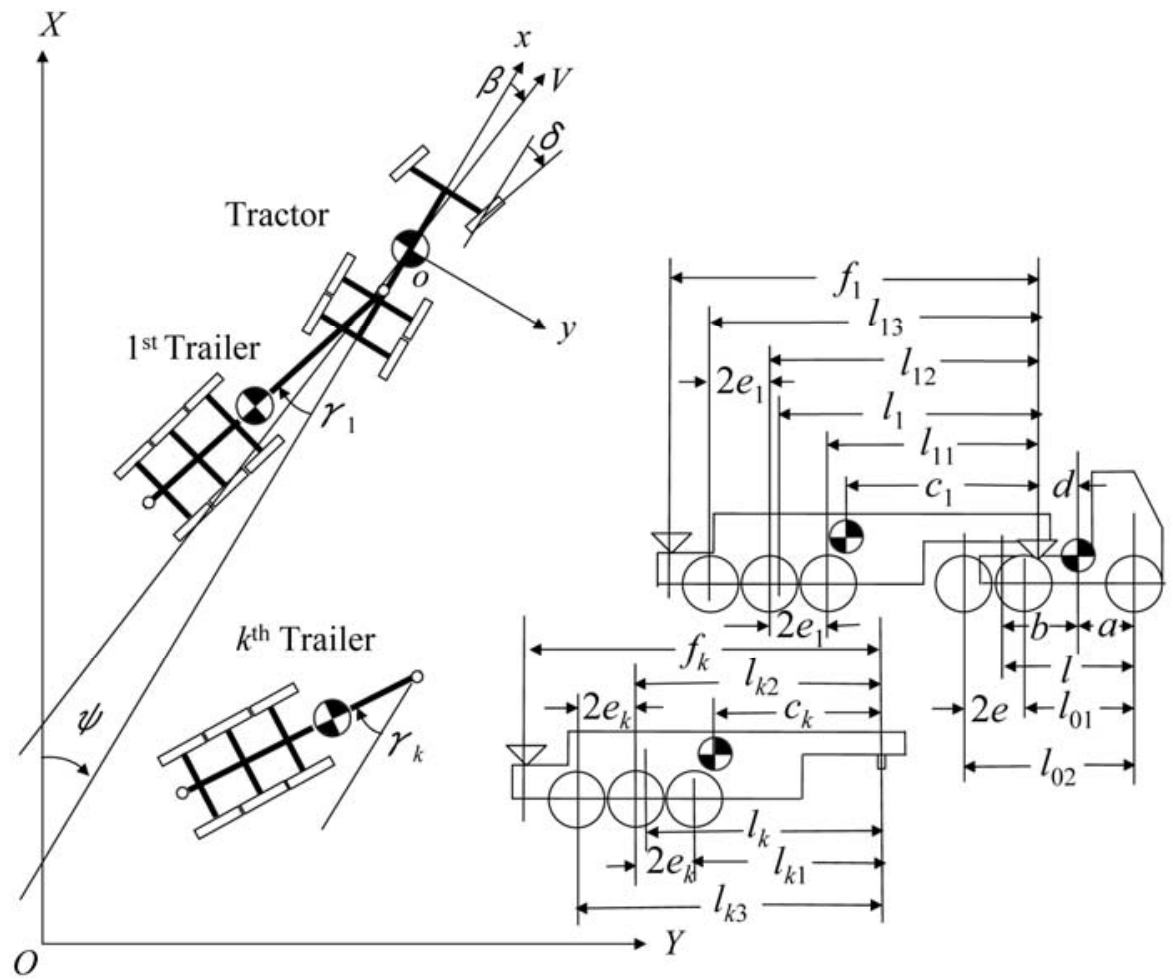

Fig. 1 Model of multi-articulated vehicles with multiple axles

\section{$2 \cdot 2$ 運動方程式}

上記の路面固定座標系に関する多軸・多重連結車両の運動方程式を付録 2 に示す．また，前報 ${ }^{(1)}$ で明らかにし たように，各車両における複数軸の各荷重が同じ場合，および同荷重が異なる場合でもタイヤのコーナリング係 数が同じと仮定できる場合は，多軸・多重連結車両の運動方程式を仮想軸・多重連結車両のそれに幾つかの項を 付加することにより簡略化できる．付録 3 に各車両における複数軸の各荷重が同じ場合の運動方程式を示す. 


\section{3. 横 方 向応答}

\section{$3 \cdot 1$ 伝達関数}

開ループ系の基本的な操舵時の横方向応答は路面固定座標系の運動方程式から求めた伝達関数から検討できる. 付録 3 に示す路面固定座標系による運動方程式から，すべての初期值を零として開ループ系の伝達関数を求める と式（1）のようになる.

$$
\begin{aligned}
& Y(s) / \Delta(s)=\sum_{i=0}^{2 n+2} \bar{k}_{i Y} s^{i} / s^{2} \sum_{i=0}^{2 n+2} k_{i} s^{i} \\
& \Psi(s) / \Delta(s)=\sum_{i=0}^{2 n+1} \bar{k}_{i \Psi} s^{i} / s \sum_{i=0}^{2 n+2} k_{i} s^{i} \\
& \Gamma_{k}(s) / \Delta(s)=\sum_{i=0}^{2 n} \bar{k}_{i k} s^{i} / \sum_{i=0}^{2 n+2} k_{i} s^{i}
\end{aligned}
$$

\section{$3 \cdot 2$ 車線乗り移り運動}

高速道路上を走行する多軸・多重連結車両の操舵入力に対する過渡応答を検討するために，車線乗り移り運動

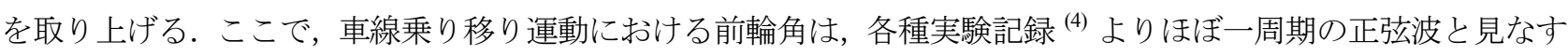
ことができる（図 2).

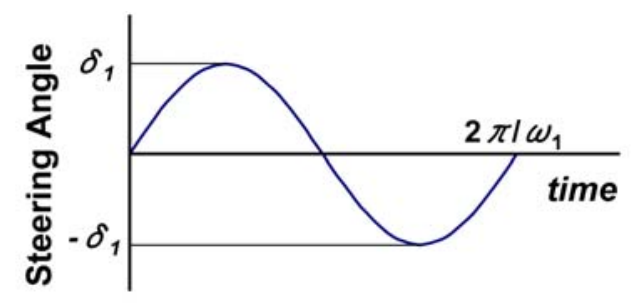

Fig. 2 Steering input of lane change maneuver

従って，上記の運動の前輪角入力は式（2）のように表現できるため，これを用いてその応答を検討する.

$$
\delta=\delta_{1} \sin \omega_{1} t\left[U(t)-U\left(t-2 \pi / \omega_{1}\right)\right]
$$

ここで， $\omega_{1}$ は操舵周波数， $\delta_{1}$ は操舵振幅， $U(t)$ は単位ステップ関数である.

\section{$3 \cdot 3$ 車線乗り移り運動における操舵の感度}

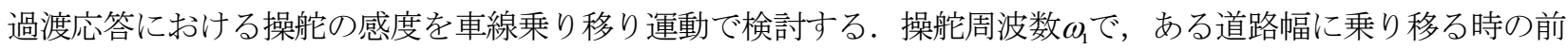
輪角の振幅 $\delta_{1}$ は，車線乗り移り運動における舵の効き具合を表している．すなわち， $\delta_{1}$ が大きければ鈍く，逆に $\delta_{1}$ が小さければ鋭いので, $1 / \delta_{1}$ を車線乗り移り時の操舵の感度と称し以下に考察する. 車線乗り移り運動における最 終乗り移り幅 $Q$ は，この系が収束する場合，式（1）の第 1 式および式（2）から以下の式（3）のように求める ことができる.

$$
Q=\lim _{t \rightarrow \infty} Y=\left(2 \pi \delta_{1} / \omega_{1}^{2}\right)\left(\bar{k}_{0 Y} / k_{0}\right)
$$

従って，一定道路幅に乗り移る場合の操舵の感度は, 以下の式 (4) で与えられる.

$$
1 / \delta_{1}=\left(2 \pi / \omega_{1}^{2} Q\right)\left(\bar{k}_{0 Y} / k_{0}\right)
$$

また, $n=2,3$ の多軸・多重連結車両では以下の式（5）が導出される. 


$$
\begin{aligned}
& \bar{k}_{0 Y}=l C_{f} C_{r} \prod_{i=1}^{n} l_{i} C_{i} \\
& k_{0}=l^{2} C_{f} C_{r} \prod_{i=1}^{n} l_{i} C_{i} F\left(1+K^{*} V^{2}\right) / V^{2}
\end{aligned}
$$

従って，式（4）は式（5）を用いると式（6）のようになる.

$$
1 / \delta_{1}=\left(2 \pi / \omega_{1}^{2} Q\right) V^{2} /\left[l F\left(1+K^{*} V^{2}\right)\right]
$$

ここで,

$$
\begin{aligned}
& K^{*}=K / F \\
& F=1+\left(A / l^{2}\right)\left(1+C_{r} / C_{f}\right)+\sum_{i=1}^{n}\left(B_{i} / l l_{i}\right)\left[D_{i}\left(C_{i} / C_{f}\right)-E_{i}\left(C_{i} / C_{r}\right)\right] \\
& D_{i}=[(b-d) / l] \prod_{j=1}^{i-1}\left(1-f_{j} / l_{j}\right) \\
& E_{i}=[(a+d) / l] \prod_{j=1}^{i-1}\left(1-f_{j} / l_{j}\right) \\
& K=\left(P_{f} / C_{f}-P_{r} / C_{r}\right) / g l \\
& P_{f}=(b / l) M g+[(b-d) / l] \sum_{i=1}^{n}\left[\prod_{j=1}^{i-1}\left(1-f_{j} / l_{j}\right)\right]\left(1-c_{i} / l_{i}\right) M_{i} g \\
& P_{r}=(a / l) M g+[(a+d) / l] \sum_{i=1}^{n}\left[\prod_{j=1}^{i-1}\left(1-f_{j} / l_{j}\right)\right]\left(1-c_{i} / l_{i}\right) M_{i} g
\end{aligned}
$$

従って, 車線乗り移り時の操舵の感度は, 過渡応答を規定する $\omega_{1}$, 運動の大きさを規定する $Q$, 多軸・多重連 結車両に固有なスタビティ・ファクタ $K^{*}{ }^{(1)}$, トラクタ前軸・同仮想後軸間距離 $l$, 係数 $F$ および速度 $V$ によって 表現される，なお，式（6）は $n=0,1$ の場合も成立する.

次に, 前報 (1)で求めた下記の式 (7) に示寸多軸・多重連結車両の定常円旋回時の操舵の感度との関係を求め る. ここで，定常円旋回時の操舵の感度は極低速度（ $V=0 ）$ と低中高速度の前輪角の比で定義されている.

$$
[\bar{\delta} / \delta]_{\text {steady }- \text { state }}=1 /\left(1+K^{*} V^{2}\right)
$$

従って，式（6）は式（7）を用いると，式（8）のようになる.

$$
1 / \delta_{1}=\left[\left(2 \pi / \omega_{1}^{2} Q\right) V^{2} / I F\right] \times[\bar{\delta} / \delta]_{\text {steady-state }}
$$

\section{$3 \cdot 4$ 車線乗り移り運動における追従性}

多軸・多重連結車両の過渡応答における追従性の指標として以下の三つを取り上げる．ここで，多軸・多重連 結車両の各車軸中心は，付録 3 の運動方程式を用いるため，各複数軸の幾何学的中心となる.

・整定時間 : 各車軸中心の応答が，操舵開始から最終值の $5 \%$ 以内に収まるまでの時間

・行き過ぎ量 : 各車軸中心の応答の最大值と最終值との差

・最大ずれ幅 : 各車軸中心の路面軌跡間のずれ幅の最大值

また，上記の三つの指標に関連して，以下の指標を追加して考察する.

・遅延時間 : 各車軸中心の応答が，操舵開始から最終值の $50 \%$ に到達するまでの時間

・立ち上がり時間 : 各車軸中心の応答が，操舵開始から最終值の $10 \%$ に到達してから $90 \%$ に至るまでの時間

・応答時間 : 遅延時間と立ち上がり時間を加算した時間（2 次系に関するステップ応答あるいはインディシヤ ル応答では最初のピークが現れる時間を応答時間と定義しているが，これは遅延時間と立ち上がり時間の和にほ ぼ等しくなるため，ここでも同様に定義する） 


\section{4. 数 值 計 算}

\section{$4 \cdot 1$ 車両諸元}

付録 4 に数值計算に用いる, 多軸に関する諸元以外の車両諸元 ${ }^{(1)}$ を示す．ここで，今回の数值計算において採 用した I 型および II 型のトラクタ・ダブルストレーラは, 国内には導入されていないため, 国産の重量級トラク タ・セミトレーラの最大積載量20トンを分割して各トレーラに10トン積載すると想定した多重連結車両である. なお，これらのトラクタ・ダブルストレーラの車両諸元は 1969 年の国内導入検討時のそれである ${ }^{(5)(6) . ま た ， 上 ~}$ 記のセミトレーラに 20 トンを積載したトラクタ・セミトレーラ，およびトラックに 8 トン，フルトレーラに 6 トンを積載したトラック・フルトレーラの車両諸元は, 国内で多く運用されているそれである.

\section{$4 \cdot 2$ 基本的な横方向応答}

多軸・多重連結車両の操舵時の基本的な横方向応答は, 操舵入力に対するトラクタの横すべりとヨーイング, およびトラクタとトレーラの相対的なヨーイングの周波数応答のゲインにより検討できる.ここでは，主要極， または減衰比が主要極と同程度である極の固有振動数および減衰固有振動数付近でゲインにピークが顕著に現れ る，トラクタとトレーラの相対ヨー角に関する周波数応答について，極・零点との関連を考察する.

図 3 および図 4 は I 型のトラクタ・ダブルストレーラ（トラクタ・セミトレーラ・セミトレーラ）およびII 型 のそれ（トラクタ・セミトレーラ・フルトレーラ）に関するゲインの計算結果である．また，比較のために国産 のトラクタ・セミトレーラおよびトラック・フルトレーラのそれを図 5 および図 6 に示している.
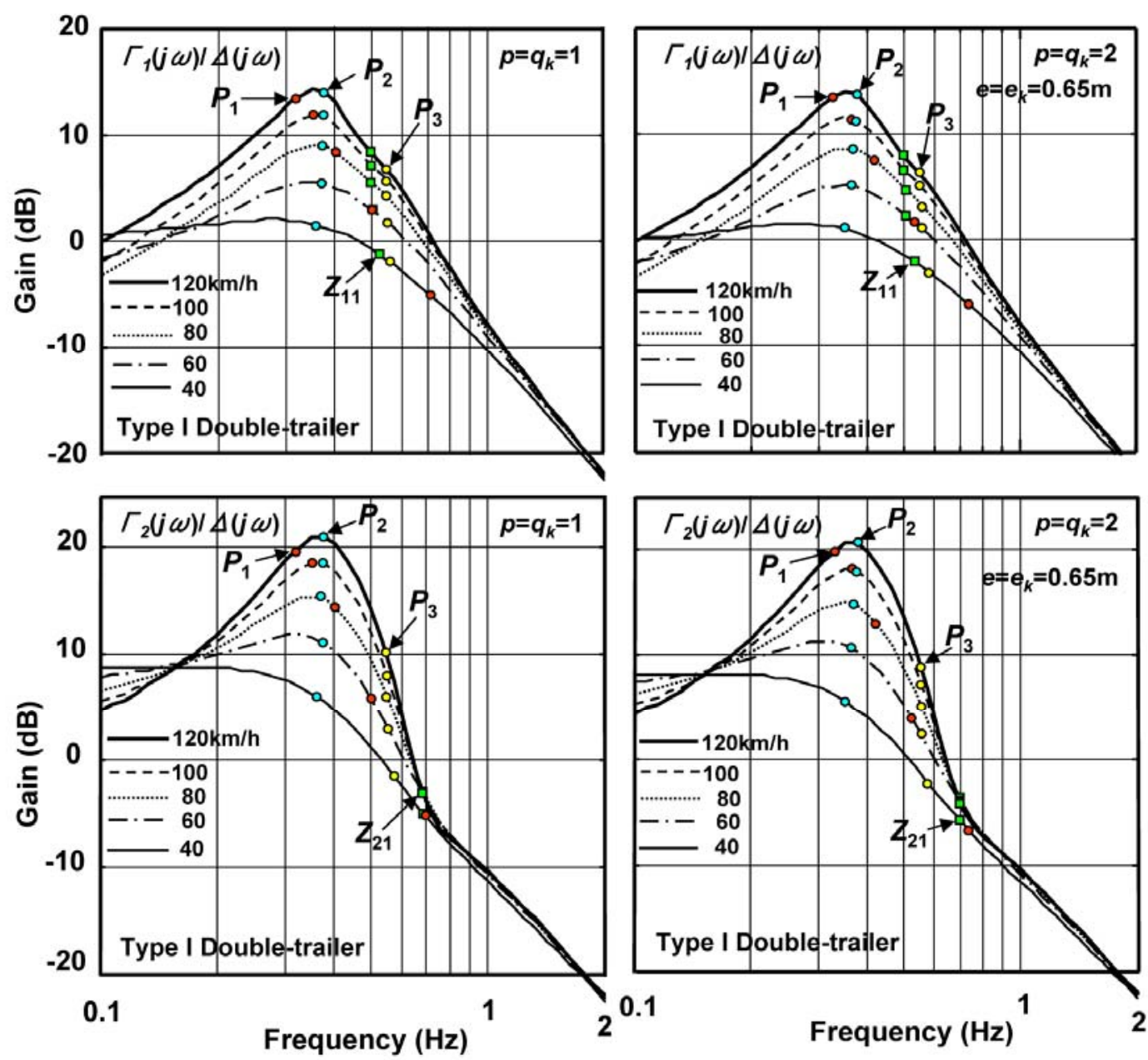

Fig. 3 Frequency response of tractor and type I double-trailer combination 

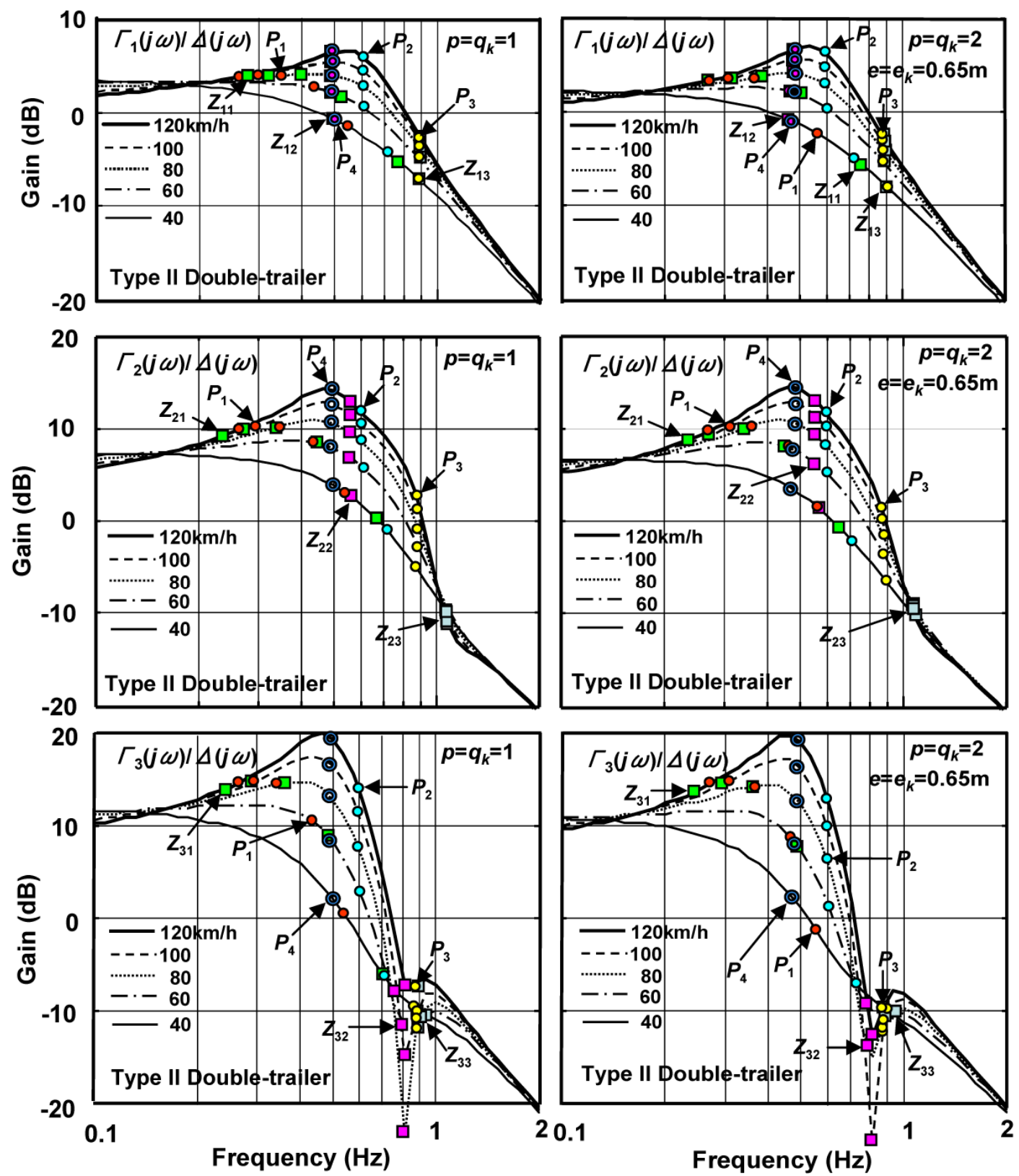

Fig. 4 Frequency response of tractor and type II double-trailer combination
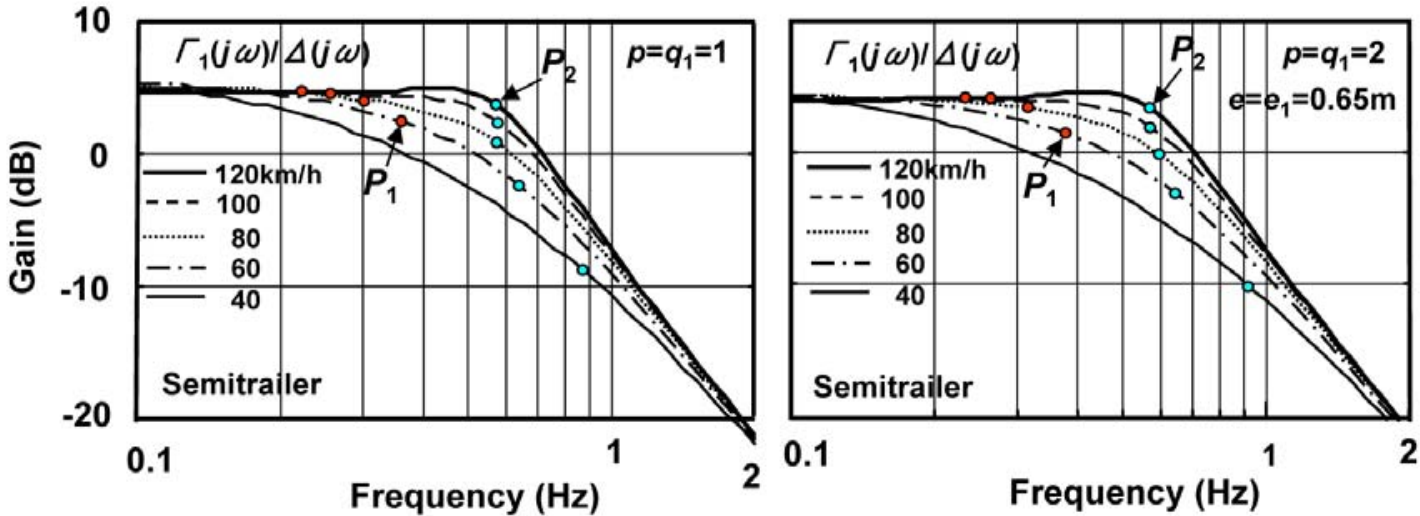

Fig. 5 Frequency response of tractor and semitrailer combination 


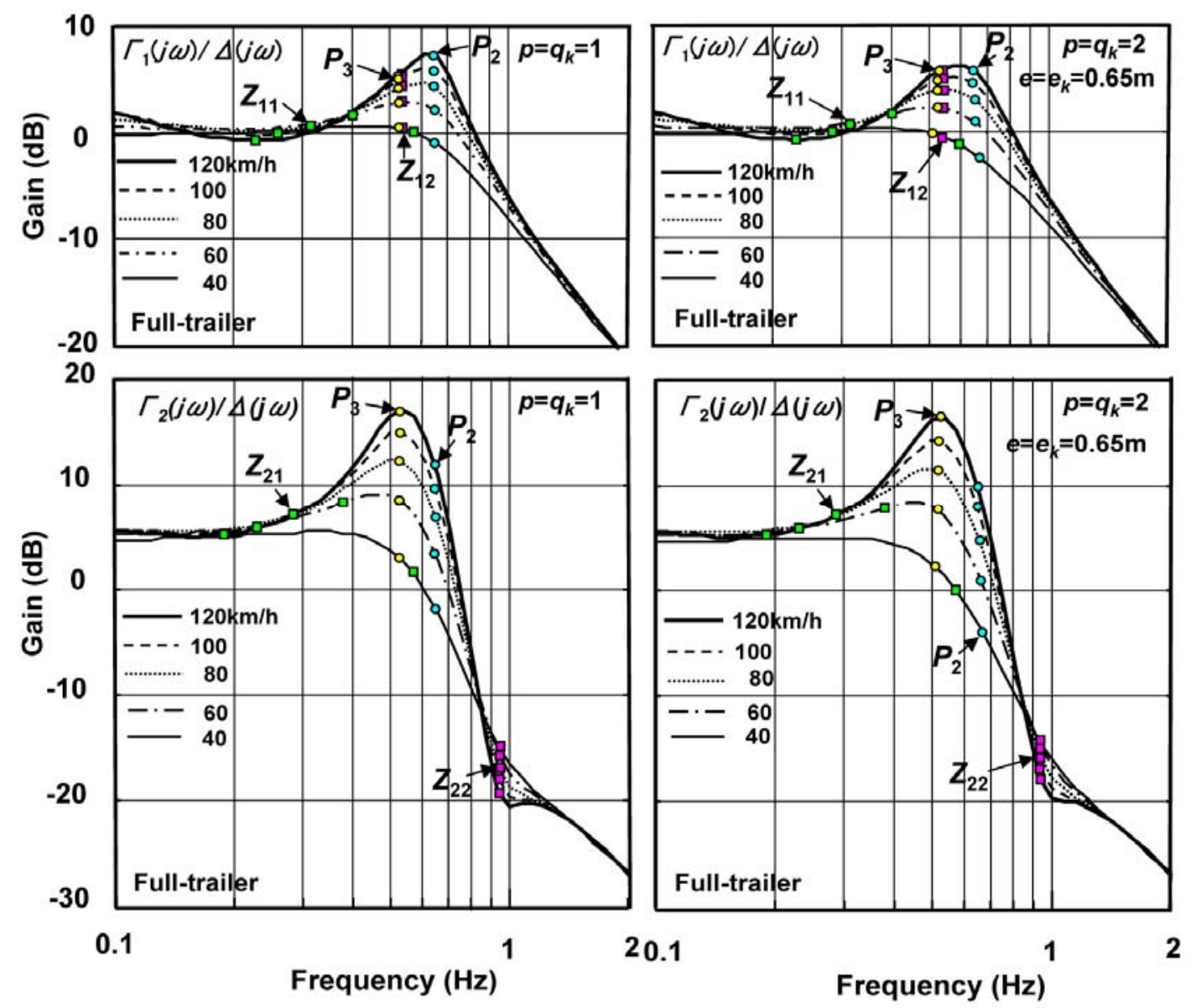

Fig. 6 Frequency response of truck and full-trailer combination

上記図中では 1 軸のそれと多軸のそれを対比して示してあり，多軸についてはトラクタ後軸および各トレーラ 軸を 2 軸とした場合について計算してある。また，速度をパラメータとした計算結果上に，極および零点の固有 振動数をそれぞれ $P_{i}$ および $Z_{k j}$ で表示してある $(i, j, k=1,2, \cdots)$. ここで, 極の固有振動数と減衰固有振動数はそ の減衰比が小さい場合には, 共振振動数とほぼ等しいため, 便宜上, 極および零点とも固有振動数を用いている. なお，図 5 において，固有振動数の表示がない極と零点は非振動根である.

まず，図 3〜図 6 の各連結車両の 1 軸の周波数応答と多軸のそれを対比すると，トラクタ・各トレーラ相対ヨ 一角は 1 軸と多軸で，全体的にみて同様の応答を示している。ここで，ピーク付近の周波数では， 1 軸のゲイン より多軸のそれが僅かに小さくなっている.

一方，応答が落ち込む周波数では，各連結車両でやや状況が異なっており，図 3 に示す $\mathrm{I}$ 型のトラクタ・ダブ ルストレーラのトラクタ・第 2 トレーラ相対ヨー角の落ち込み量が 1 軸より多軸がやや大きくなっているのに対 して，図 4 および図 6 に示す II 型のトラクタ・ダブルストレーラおよびトラック・フルトレーラのそれが 1 軸よ り多軸がやや小さくなっている。 また，図 4 のトラクタ・第 3 トレーラ相対ヨー角については $0.8 \mathrm{~Hz}$ 付近の落ち 込み量が大きく，第 2 ピークが接近している.

次に，各連結車両の周波数応答のゲインおよび極・零点の関連についてみる．極の減衰比が小さければピーク 值が大きくなり，零点の減衰比が小さければ落ち込み量が大きくなる.また極と零点の固有振動数が近ければ, 相互干渉によりゲインが決まる. 図 3～図 6 の各連結車両のトラクタ・第 1 および第 2 トレーラ相対ヨー角につ いては，図示された極と零点の固有振動数をみると上記の通りとなっている.ここで，図 4 のトラクタ・第 1 卜 レーラ相対ヨ一角の $P_{4}$ と $Z_{12}$ および $P_{3}$ と $Z_{13}$ は固有振動数と減衰比が非常に近い值であるが，完全には一致して いないため，伝達関数における分子と分母の低次数化はできない。一方，図 4 に示寸トラクタ・第 3 トレーラ相 対ヨー角の $0.5 \mathrm{~Hz}$ 付近のピークについては極と零点の関連はトラクタ・第 1 および第 2 トレーラ相対ヨー角の場 合と同様であるが，0.7〜 1Hz ではそれが上記のように複雑である. 
図 7 は速度をパラメータとした, II 型のトラクタ・ダブルストレーラの極 $P_{3}$ およびトラクタ・第 3 トレーラ相 対ヨ一角に関する零点 $Z_{32} \cdot Z_{33}$ を減衰比と固有振動数で示した図である。これをみると, 1 軸および多軸とも, 高速で, $P_{3}$ および $Z_{33}$ の固有振動数が接近しており，これらの根が干渉するとともに， $Z_{32}$ が負の減衰比を持ち応 答が急激に落ち込むことが分かる.

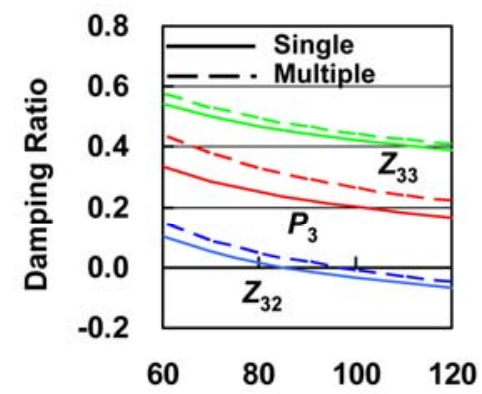

Forward Velocity $(\mathbf{k m} / \mathrm{h})$

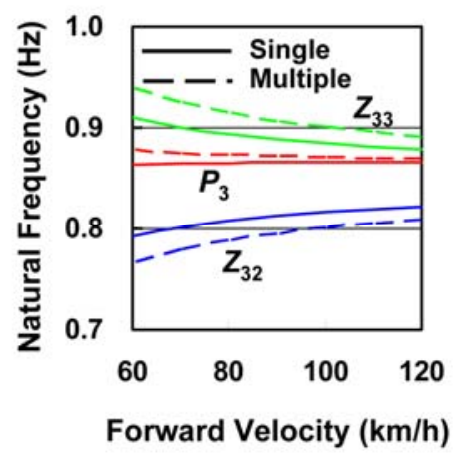

Fig. 7 Pole and zero of tractor and type II double-trailer combination

さて，多軸に関するパラメータが周波数応答のピークと落ち込みに及ぼす影響は極と零点の減衰比によって検 討できる．ここでは，極の減衰比の計算結果は前報 ${ }^{(1)}$ で報告しているため，図 8〜図 10 に示す零点のそれにつ いて述べる.

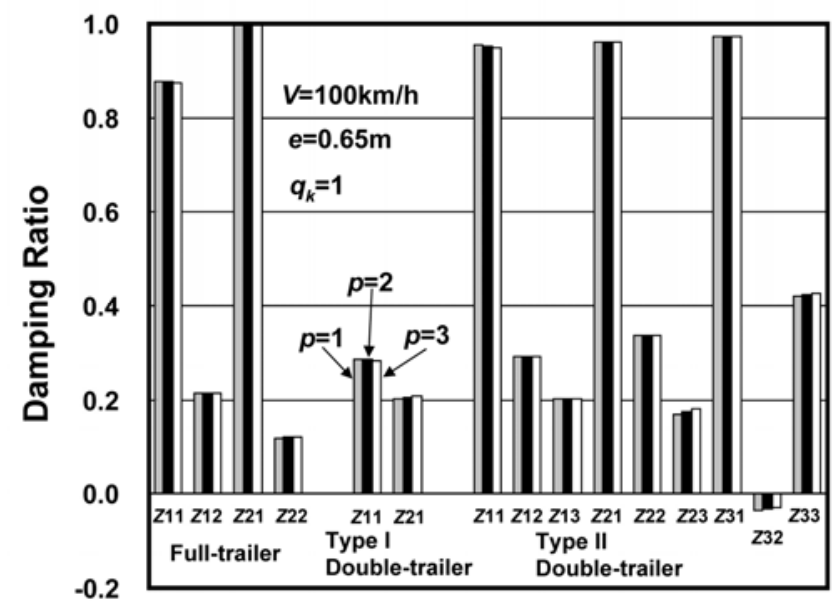

Fig. 8 Damping ratio of zero of vehicle combinations (parameter: $p$ )

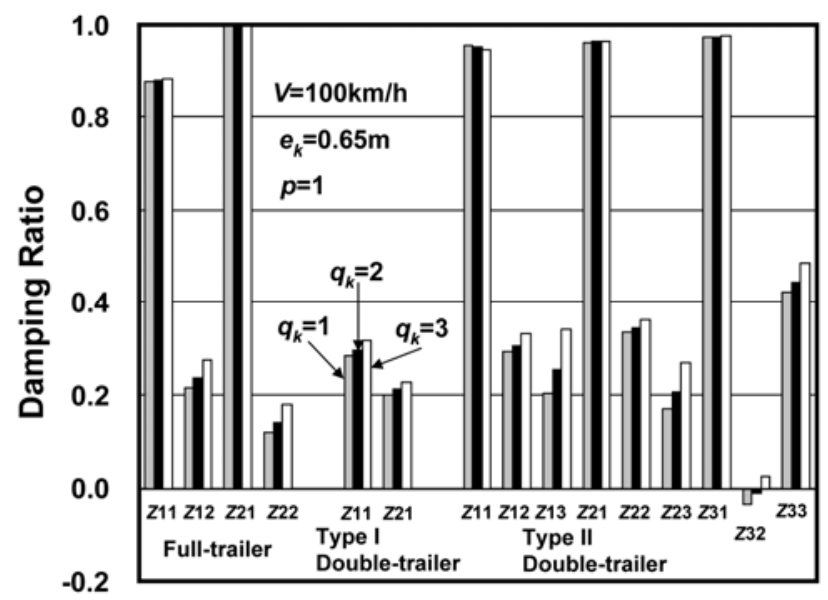

Fig. 9 Damping ratio of zero of vehicle combinations (parameter: $q_{k}, k=1 \sim 3$ ) 


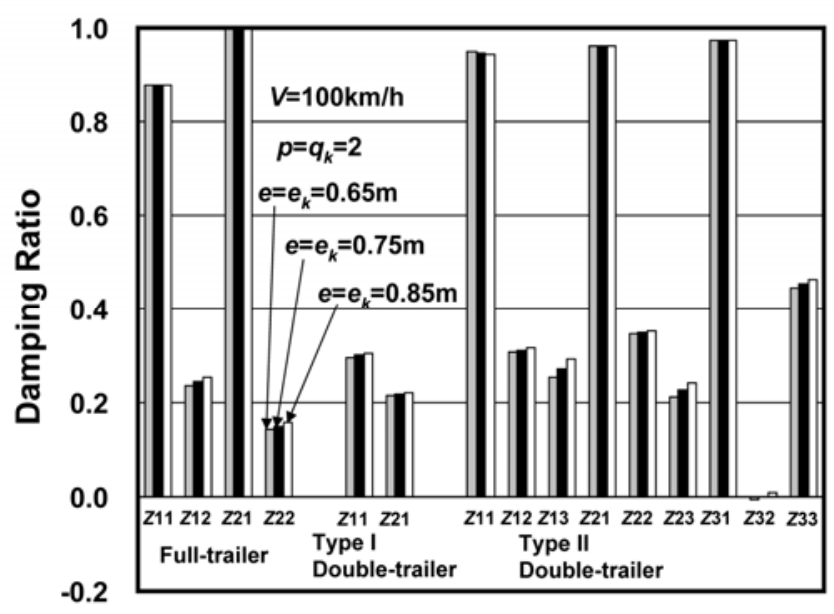

Fig. 10 Damping ratio of zero of vehicle combinations (parameter: $e=e_{k}, k=1 \sim 3$ )

図 8 は各トレーラ軸を 1 軸にしてトラクタまたはトラックの後軸のみを 2 軸および 3 軸にした場合, 図 9 はト ラクタまたはトラックの後軸を 1 軸にして各トレーラ軸を 2 軸および 3 軸にした場合の速度 $100 \mathrm{~km} / \mathrm{h}$ における計 算結果である. また, 図 10 はトラクタまたはトラックの後軸および各トレーラ軸を 2 軸にしてその軸間距離を変 化させた場合のそれである．これらの計算結果をみると，ほとんどの零点の減衰比が，各車両の軸数および軸間 距離の増加に従って大きくなる傾向を示している. また，多軸に関するパラメータの中で各トレーラの軸数が零 点の滅衰比に与える影響が大きい.

一方，前報 ${ }^{(1)}$ では，II 型のトラクタ・ダブルストレーラの極 $\mathrm{P}_{3}$ において第 2 トレーラに相当するドーリーの みを多軸にした場合に減衰比が大きくなり振動安定性を向上することができるという結果が得られている. 図 11 は，II 型のトラクタ・ダブルストレーラの一つのトレーラ軸のみを 2 軸にして他のトレーラ軸を 1 軸にした場合 の零点の減衰比の計算結果であるが，ここでもドーリーの多軸化が $Z_{32}$ と $Z_{33}$ の減衰比を大きくしている. 従って ドーリーの多軸化がトラクタ・第 3 トレーラ相対ヨー角の周波数応答のピーク值を小さくすると共に，落ち込み 量を少なくすることが分かる.

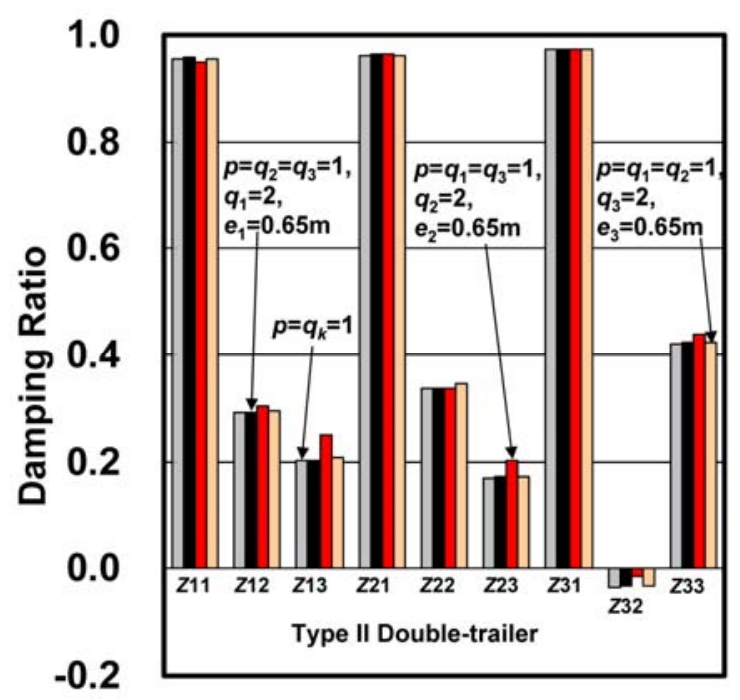

Fig. 11 Damping ratio of zero of tractor and type II double-trailer combination (parameter: $q_{k}, k=1 \sim 3, V=100 \mathrm{~km} / \mathrm{h}$ ) 


\section{$4 \cdot 3$ 車線乗り移り運動における追従性と操舵の感度との関連}

図 12〜図 14 に車線乗り移り運動における各連結車両の整定時間, 行き過ぎ量および最大ずれ幅を示す. 各図 中には，トラクタ後軸および各トレーラ軸を 2 軸とした I 型および II 型のトラクタ・ダブルストレーラの速度 $100 \mathrm{~km} / \mathrm{h}$ の計算結果を 1 軸のそれと共に示している. また, 図中には比較のために国産のトラクタ・セミトレー ラおよびトラック・フルトレーラのそれらも示してある. なお， パラメータは操舵時間 $2 \pi / \omega_{1}$ である.

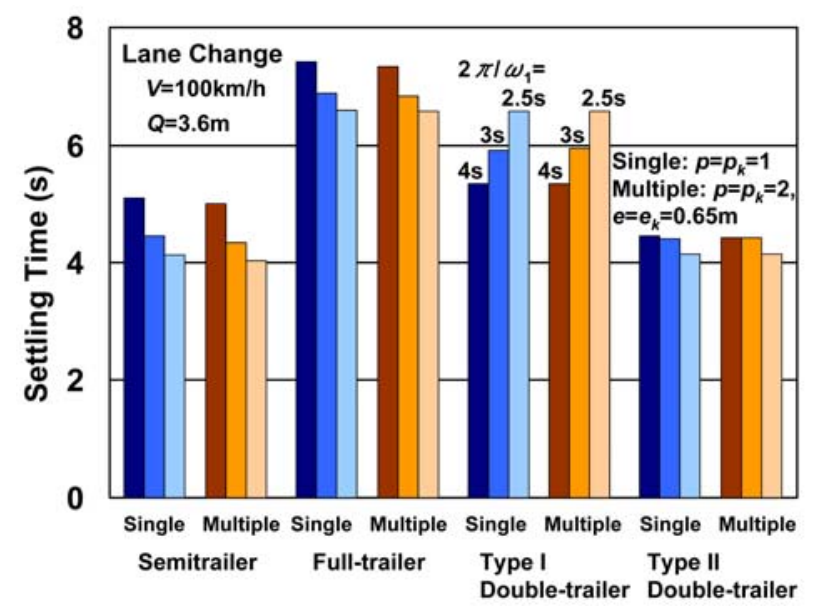

Fig. 12 Settling time of vehicle combinations in lane change maneuver

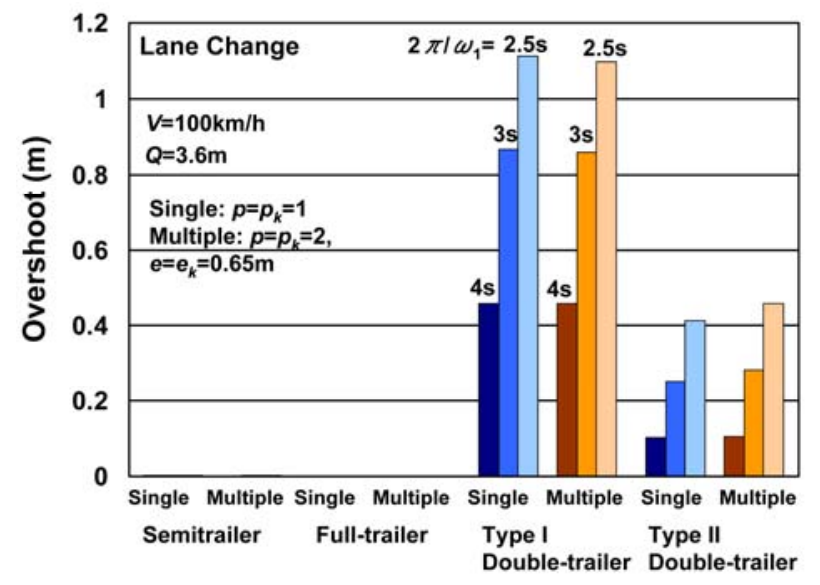

Fig. 13 Overshoot of vehicle combinations in lane change maneuver

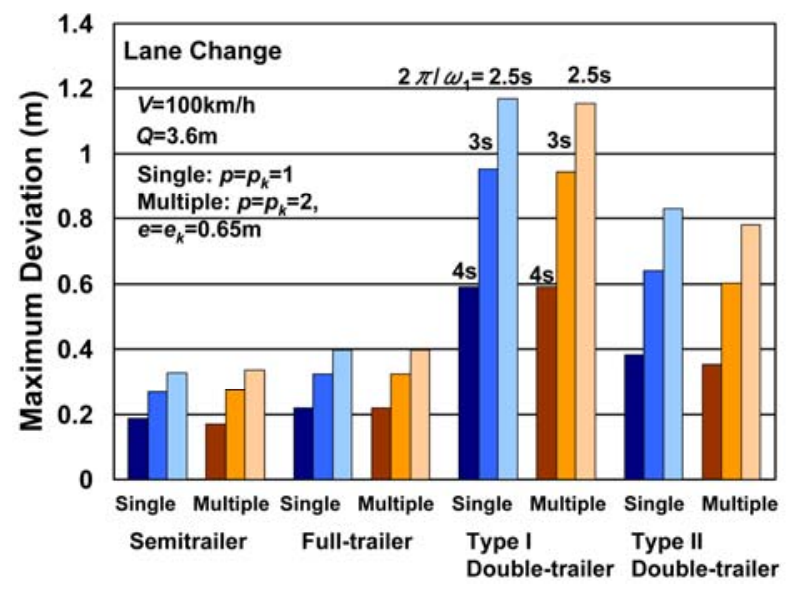

Fig. 14 Maximum deviation of vehicle combinations in lane change maneuver 
まず，図 12 から整定時間をみると，操舵時間が短くなるにつれて，後述の理由で，この指標が短くなる連結車 両と長くなるそれに分かれている。ここで，前者にはトラクタ・セミトレーラ，トラック・フルトレーラおよび II 型のトラクタ・ダブルストレーラが，後者には I 型のトラクタ・ダブルストレーラが該当する．また，トラッ ク・フルトレーラ， I 型のトラクタ・ダブルストレーラ, トラクタ・セミトレーラおよび II 型のトラクタ・ダブ ルストレーラの順で整定時間が短くなっている. 次に, 図 13 から行き過ぎ量をみると, この指標がほぼ零および 零の連結車両と大きな值を持つ車両に分かれている，ここで，前者はトラクタ・セミトレーラおよびトラック・ フルトレーラ, 後者は I 型および II 型のトラクタ・ダブルストレーラである. また, 後者は操舵時間が短くなる につれて行き過ぎ量が増加し, 特に, I 型のトラクタ・ダブルストレーラのそれが大きな值を示している. さら に, 図 14 から最大ずれ幅をみると, トラクタ・セミトレーラおよびトラック・フルトレーラの值に比べて, 多重 連結車両である I 型および II 型のトラクタ・ダブルストレーラのそれが非常に大きくなっていることがわかる. なお，各連結車両の上記の三つの指標は，1軸と多軸で大きな差異はない.

次に，上記の三つの指標に関連して，ステップ応答あるいはインディシャル応答で用いられる，遅延時間，立 ち上がり時間および応答時間を検討する, 図 15 に多軸の各連結車両の各軸の遅延時間と立ち上がり時間を示す. また，図 16 に遅延時間と立ち上がり時間を合計した応答時間を示寸.ここで，図中の $f, r, 1 \sim 3$ はトラクタ前 軸，同後軸および各トレーラ軸を表示している，これらをみると，各連結車両とも車両後部の軸ほど遅延時間は 長くなり，逆に立ち上がり時間は短くなっている．また，応答時間はやや短くなる傾向を示すが，その值は各軸 で差は少ない，また，遅延時間および立ち上がり時間ともトラック・フルトレーラが他の連結車両に比べて大き くなっているが, これは, この連結車両の各軸の応答が緩やかに最終乗り移り車線に収束しているためで, 操舵 の感度との関連が考えられるため以下で考察する. なお, 1 軸の連結車両でも同様の結果である.
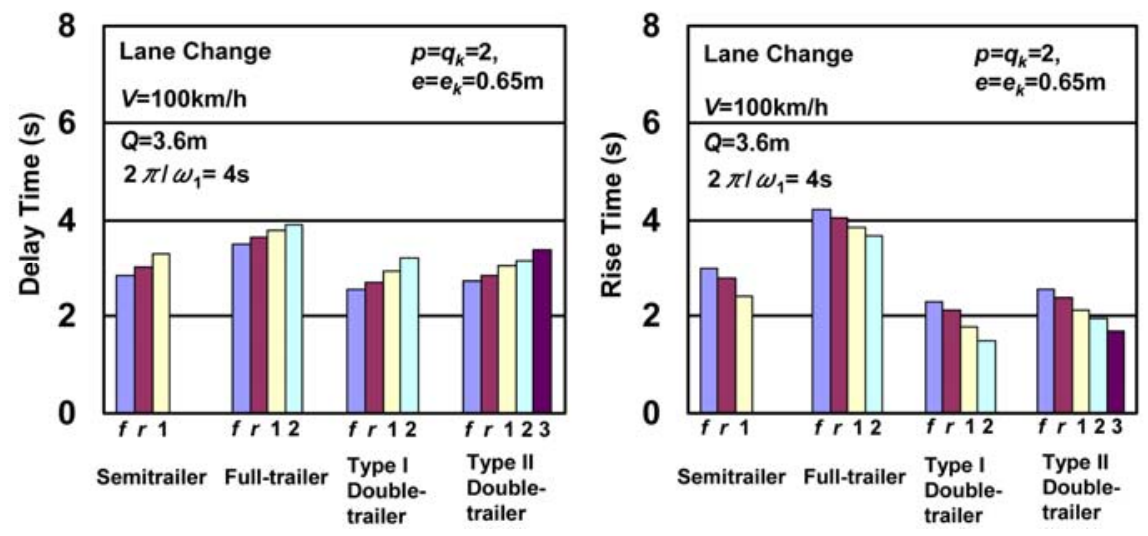

Fig. 15 Delay and rise time of vehicle combinations in lane change maneuver

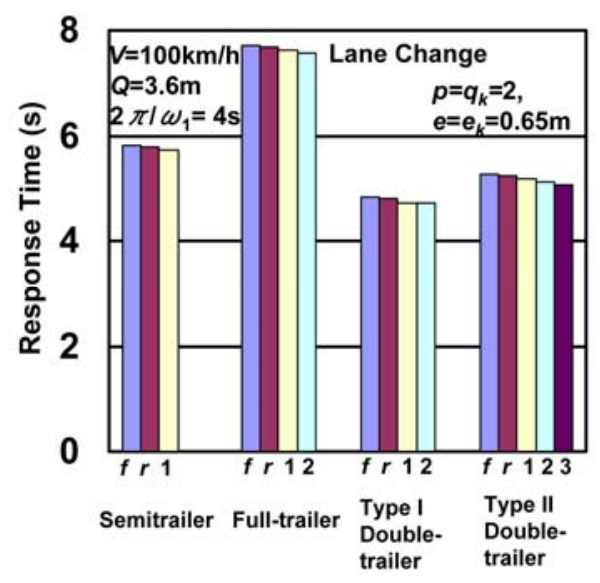

Fig. 16 Response time of vehicle combinations in lane change maneuver 
さて, 本研究における車線乗り移り運動における応答は，ある一定の道路幅に乗り移るときの操舵振幅に依存 している. 図 17 は操舵の感度の計算結果である.これをみると, 1 軸および多軸とも高速度での操舵の感度は, I 型のトラクタ・ダブルストレーラ，トラクタ・セミトレーラ， II 型のトラクタ・ダブルストレーラおよびトラッ ク・フルトレーラの順で大きくなっている. なお， トラクタ・セミトレーラと II 型のトラクタ・ダブルストレー ラの操舵の感度は速度により順が逆転しているが，その差が少ない。ここで，トラック・フルトレーラは減衰比 の小さな振動モードを持っている (7) が, 操舵の感度が大きく, 従って操舵振幅が小さく, 応答が緩やかに漸近線 の状態で最終乗り移り車線に移行するため，行き過ぎ量が零であり，最大ずれ幅も比較的小さい. 一方，整定時 間は長い. トラクタ・セミトレーラと II 型のトラクタ・ダブルストレーラは, トラック・フルトレーラよりも操 舵の感度が小さいため, より大きく操舵する。しかしながら，トラクタ・セミトレーラは比較的大きな減衰比の 振動モードを持つため ${ }^{(7)}$, 応答は緩やかであり, 行き過ぎ量はほぼ零であり, 最大ずれ幅も小さい. これに対し て, II 型のトラクタ・ダブルストレーラは小さな減衰比の振動モードを持つため (7) , 行き過ぎ量および最大ずれ 幅ともやや大きくなっている，さらに，I 型のトラクタ・ダブルストレーラは，他の連結車両と比べて操舵の感 度が小さく, 従って大きな操舵振幅が必要であるため, 操舵の立ち上がりが急である. また, その振動モ一ドに 関する極も小さな減衰比を持っている (7) ため, 応答は振動的になっており, 急な操舵の立ち上がりと共に, 行き 過ぎ量が大きく，整定時間も長くなっている，従って最大ずれ幅も大きい.

最後に, 前述の操舵時間の減少と整定時間の長短の関係が車両により分かれる理由は以下のとおりである.ま ず，操舵振幅が小さく，応答が緩やかに漸近線の状態で最終乗り移り車線に収束する連結車両は，操舵時間の減 少に対応して整定時間も減少する。一方, 操舵振幅が大きく, 減衰比の小さい振動モードを持つ連結車両は, 操 舵時間の減少に対応して, 応答がより激しい振動状態になるため収束が遅れ, 整定時間が増加する.

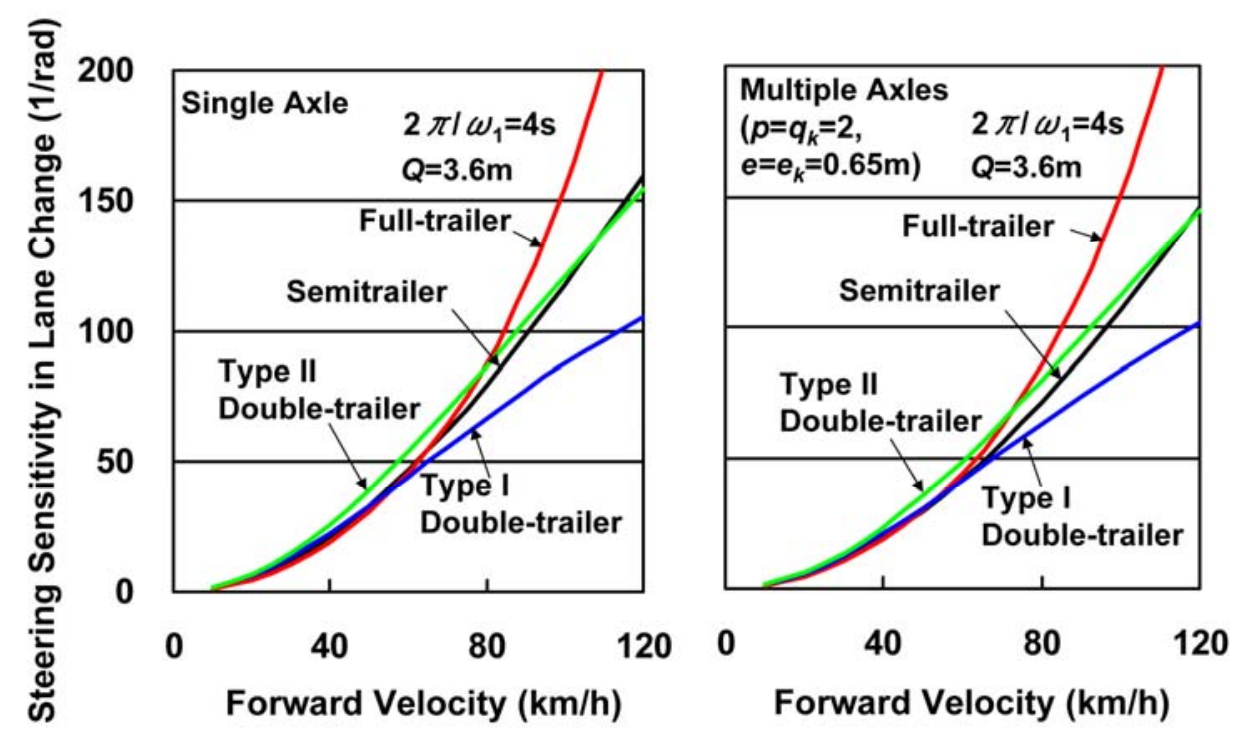

Fig. 17 Steering sensitivity of vehicle combinations in lane change maneuver

\section{5. むすび}

本研究では，まず，多軸・多重連結車両の各車両の複数軸を仮想軸に変換した運動方程式を用いて，操舵入力 に対する各変数の伝達関数を求め, 次に車線乗り移り運動における操舵の感度の定式化, および追従性の指標の 定義をおこなっている. また，数值計算により，二種類のトラクタ・ダブルストレーラ，国産のトラクタ・セミ トレーラおよびトラック・フルトレーラについて, 周波数応答のゲインと極・零点との関連, 各变数に関する伝 達関数の零点に及ぼす多軸に関するパラメータの影響を検討している. さらに，車線乗り移り運動における追従 性と操舵の感度との関連を考察している。

本研究で得られた主な結果をまとめると以下のようになる. 
（1）多軸・多重連結車両の車線乗り移り時の操舵の感度は，操舵時間，乗り移り幅，多軸・多重連結車両に固 有なスタビリティ・ファクタ，トラクタ前軸・同仮想後軸間距離，多軸に関する係数および速度によって表現さ れる．また，この操舵の感度は，定常円旋回時の操舵の感度を式の一部に含む.

（2）各トレーラの軸数が零点の減衰比に与える影響は, 極の減衰比に及ぼす影響と同様に, 多軸に関するパラ メータの中で大きい. 特に, II 型のトラクタ・ダブルストレーラのドーリーの多軸化が, トラクタに対する最後 尾トレーラの相対ヨー角の周波数応答のゲインの第 2 ピーク付近の落ち込み量を少なくする.

（3）車線乗り移り時の操舵の感度が小さく, 減衰比の小さい振動モードを持つ I 型のトラクタ・ダブルストレ 一ラは, 他の連結車両と比べて, 大きな操舵を必要とするため, 操舵の立ち上がりが急であり, 行き過ぎ量が大 きく，整定時間も長い，従って最大ずれ幅も大きい.

\section{謝 辞}

本研究の数值計算にご支援頂いた日本大学大学院の野見山龍介氏に謝意を表します.

\section{付録 1 記 号}

$a \quad$ : トラクタ前軸・同重心間距離

$b \quad$ : トラクタ重心・同仮想後軸間距離

$c_{k} \quad:$ 第 $k$ トレーラ前部連結点・同重心間距離

$d \quad$ : トラクタ重心・同連結点間距離

$2 e \quad$ : トラクタ後軸隣接軸間距離

$2 e_{k} \quad$ : 第 $k$ トレーラ軸隣接軸間距離

$f_{k} \quad$ : 第 $k$ トレーラ前後部連結点間距離

$l \quad:$ トラクタ前軸・同仮想後軸間距離

$l_{o m} \quad:$ トラクタ前軸・同第 $m$ 後軸間距離

$l_{k} \quad:$ 第 $k$ トレーラ前部連結点・同仮想軸間距離

$l_{k m} \quad$ : 第 $k$ トレーラ前部連結点・同第 $m$ 軸間距離

$M$ : トラクタ質量

$M_{k} \quad$ : 第 $k$ トレーラ質量

$I \quad$ ：トラクタヨー慣性モーメント

$I_{k} \quad$ : 第 $k$ トレーラョー慣性モーメント

$C_{f} \quad$ : トラクタ前輪コーナリングパワ

$C_{r} \quad$ : トラクタ仮想後輪コーナリングパワ

$C_{r_{m}}$ : トラクタ第 $m$ 後輪コーナリングパワ

$C_{k} \quad$ : 第 $k$ トレーラ仮想輪コーナリングパワ

$C_{k m}$ : 第 $k$ トレーラ第 $m$ 輪コーナリングパワ

$P_{f} \quad$ : トラクタ前軸荷重

$P_{r} \quad$ : トラクタ仮想後軸荷重

$P_{m} \quad$ : トラクタ第 $m$ 後軸荷重

$P_{c k} \quad:$ 第 $k$ トレーラ前部連結点荷重

$P_{k} \quad$ : 第 $k$ トレーラ仮想軸荷重

$P_{k m} \quad$ : 第 $k$ トレーラ第 $m$ 軸荷重

$\beta \quad$ : トラクタ重心横すべり角

$\beta_{f} \quad$ : トラクタ前輪横すべり角

$\beta_{r} \quad$ ：トラクタ仮想後輪横すべり角

$\beta_{r m} \quad$ : トラクタ第 $m$ 後輪横すべり角 


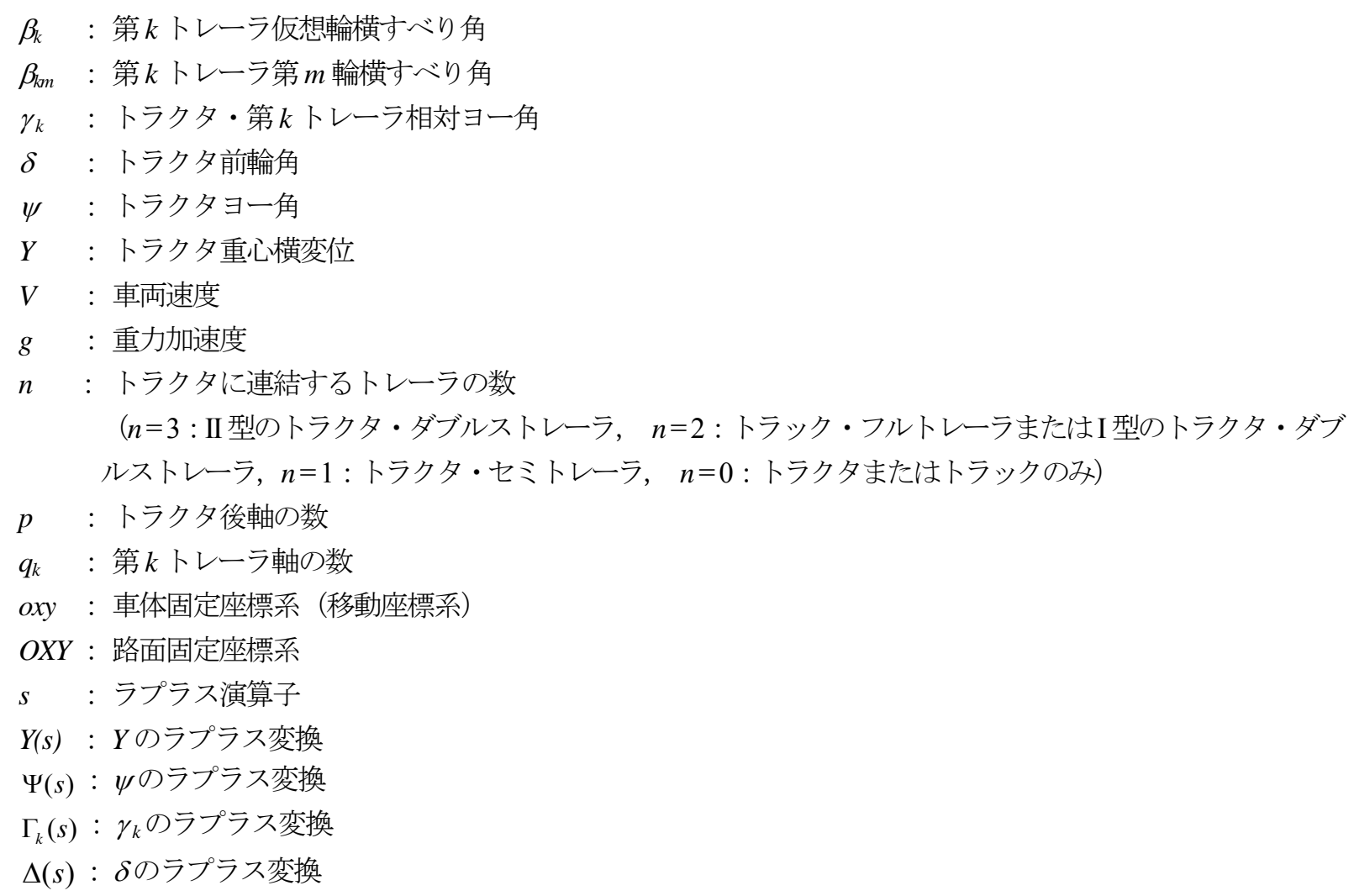

付録 2 多軸・多重連結車両の運動方程式（路面固定座標系）

$$
\begin{aligned}
& \left(M+\sum_{i=1}^{n} M_{i}\right) \ddot{Y}+\left(C_{f}+\sum_{m=1}^{p} C_{r m}+\sum_{i=1}^{n} \sum_{m=1}^{q_{i}} C_{i m}\right) \dot{Y} / V-\sum_{j=1}^{n} M_{j}\left(d+\sum_{i=1}^{j-1} f_{i}+C_{j}\right) \ddot{\psi} \\
& +\left[a C_{f}-\sum_{m=1}^{p}\left(l_{0 m}-a\right) C_{r m}-\sum_{j=1}^{n} \sum_{m=1}^{q_{j}}\left(d+\sum_{i=1}^{j-1} f_{i}+l_{j m}\right) C_{j m}\right] \dot{\psi} / V-\left(C_{f}+\sum_{m=1}^{p} C_{r m}+\sum_{i=1}^{n} \sum_{m=1}^{q_{i}} C_{i m}\right) \psi \\
& -\sum_{j=1}^{n}\left(M_{j} C_{j}+\sum_{i=j+1}^{n} M_{i} f_{j}\right) \ddot{\gamma}_{j}-\sum_{j=1}^{n}\left(\sum_{m=1}^{q_{j}} l_{j m} C_{j m}+f_{j} \sum_{i=j+1}^{n} \sum_{m=1}^{q_{i}} C_{i m}\right) \dot{\gamma}_{j} / V-\sum_{j=1}^{n} \sum_{m=1}^{q_{j}} C_{j m} \gamma_{j}=C_{f} \delta
\end{aligned}
$$$$
M d \ddot{Y}+\left[(a+d) C_{f}+\sum_{m=1}^{p}\left(a+d-l_{0 m}\right) C_{r m}\right] \dot{Y} / V+I \ddot{\psi}
$$$$
+\left[a(a+d) C_{f}-\sum_{m=1}^{p}\left(l_{0 m}-a\right)\left(a+d-l_{0 m}\right) C_{r m}\right] \psi / V-\left[(a+d) C_{f}+\sum_{m=1}^{p}\left(a+d-l_{0 m}\right) C_{r m}\right] \psi=(a+d) C_{f} \delta
$$$$
-\left(M_{k} c_{k}+\sum_{i=k+1}^{n} M_{i} f_{k}\right) \ddot{Y}-\left(\sum_{m=1}^{q_{k}} l_{k m} C_{k m}+f_{k} \sum_{i=k+1}^{n} \sum_{m=1}^{q_{i}} C_{i m}\right) \dot{Y} / V+\left[I_{k}+M_{k} c_{k}\left(d+\sum_{i=1}^{k-1} f_{i}+c_{k}\right)+\sum_{j=k+1}^{n} M_{j}\left(d+\sum_{i=1}^{j-1} f_{i}+c_{j}\right) f_{k}\right] \ddot{\psi}
$$$$
+\left[\sum_{m=1}^{q_{k}} l_{k m}\left(d+\sum_{i=1}^{k-1} f_{i}+l_{k m}\right) C_{k m}+f_{k} \sum_{j=k+1}^{n} \sum_{m=1}^{q_{j}}\left(d+\sum_{i=1}^{j-1} f_{i}+l_{j m}\right) C_{j m}\right] \dot{\psi} / V+\left(\sum_{m=1}^{q_{k}} I_{k m} C_{k m}+f_{k} \sum_{i=k+1}^{n} \sum_{m=1}^{q_{i}} C_{i m}\right) \psi
$$$$
+\sum_{j=1}^{k-1}\left(M_{k} c_{k}+\sum_{i=k+1}^{n} M_{i} f_{k}\right) f_{j} \ddot{\gamma}_{j}+\left(I_{k}+M_{k} c_{k}^{2}+\sum_{i=k+1}^{n} M_{i} f_{k}^{2}\right) \ddot{\gamma}_{k}+\sum_{j=k+1}^{n}\left(M_{j} c_{j}+\sum_{i=j+1}^{n} M_{i} f_{j}\right) f_{k} \ddot{\gamma}_{j}
$$$$
+\sum_{j=1}^{k-1}\left(\sum_{m=1}^{q_{k}} l_{k m} C_{k m}+f_{k} \sum_{i=k+1}^{n} \sum_{m=1}^{q_{i}} C_{i m}\right) f_{j} \dot{\gamma}_{j} / V+\left(\sum_{m=1}^{q_{k}} l_{k m}{ }^{2} C_{k m}+f_{k}{ }^{2} \sum_{i=k+1}^{n} \sum_{m=1}^{q_{i}} C_{i m}\right) \dot{\gamma}_{k} / V+f_{k} \sum_{j=k+1}^{n}\left(\sum_{m=1}^{q_{j}} l_{j m} C_{j m}+f_{j} \sum_{i=j+1}^{n} \sum_{m=1}^{q_{i}} C_{i m}\right) \dot{\gamma}_{j} / V
$$$$
+\sum_{m=1}^{q_{k}} l_{k m} C_{k m} \gamma_{k}+f_{k} \sum_{i=k+1}^{n} \sum_{m=1}^{q_{i}} C_{i m} \gamma_{i}=0
$$ 
$\beta=\dot{Y} / V-\psi$

$\beta_{f}=\delta-\beta-a r / V$

$\beta_{r m}=-\beta+\left(l_{0 m}-a\right) r / V$

$\beta_{k m}=-\beta+\left(d+\sum_{i=1}^{k-1} f_{i}+l_{k m}\right) r / V+\sum_{i=1}^{k-1} f_{i} \dot{\gamma}_{i} / V+l_{k m} \dot{\gamma}_{k} / V+\gamma_{k}$

\section{付録 3 複数軸を 1 軸の仮想軸に变換した多軸・多重連結車両の運動方程式（路面固定座標系）}

$$
\begin{aligned}
& \left(M+\sum_{i=1}^{n} M_{i}\right) \ddot{Y}+\left(C_{f}+C_{r}+\sum_{i=1}^{n} C_{i}\right) \dot{Y} / V \\
& -\sum_{j=1}^{n} M_{j}\left(d+\sum_{i=1}^{j-1} f_{i}+c_{j}\right) \ddot{\psi}+\left[a C_{f}-b C_{r}-\sum_{j=1}^{n}\left(d+\sum_{i=1}^{j-1} f_{i}+l_{j}\right) C_{j}\right] \dot{\psi} / V-\left(C_{f}+C_{r}+\sum_{i=1}^{n} C_{i}\right) \psi \\
& -\sum_{j=1}^{n}\left(M_{j} C_{j}+\sum_{i=j+1}^{n} M_{i} f_{j}\right) \ddot{\gamma}_{j}-\sum_{j=1}^{n}\left(l_{j} C_{j}+f_{j} \sum_{i=j+1}^{n} C_{i}\right) \dot{\gamma}_{j} / V-\sum_{j=1}^{n} C_{j} \gamma_{j}=C_{f} \delta \\
& M d \ddot{Y}+\left[(a+d) C_{f}+(d-b) C_{r}\right] \dot{Y} / V \\
& +I \ddot{\psi}+\left[a(a+d) C_{f}-b(d-b) C_{r}+A C_{r}\right] \dot{\psi} / V-\left[(a+d) C_{f}+(d-b) C_{r}\right] \psi=(a+d) C_{f} \delta \\
& -\left(M_{k} C_{k}+\sum_{i=k+1}^{n} M_{i} f_{k}\right) \ddot{Y}-\left(l_{k} C_{k}+f_{k} \sum_{i=k+1}^{n} C_{i}\right) \dot{Y} / V+\left[I_{k}+M_{k} C_{k}\left(d+\sum_{i=1}^{k-1} f_{i}+C_{k}\right)+\sum_{j=k+1}^{n} M_{j}\left(d+\sum_{i=1}^{j-1} f_{i}+C_{j}\right) f_{k}\right] \ddot{\psi} \\
& +\left[l_{k}\left(d+\sum_{i=1}^{k-1} f_{i}+l_{k}\right) C_{k}+B_{k} C_{k}+f_{k} \sum_{j=k+1}^{n}\left(d+\sum_{i=1}^{j-1} f_{i}+l_{j}\right) C_{j}\right] \dot{\psi} / V+\left(l_{k} C_{k}+f_{k} \sum_{i=k+1}^{n} C_{i}\right) \psi \\
& +\sum_{j=1}^{k-1}\left(M_{k} C_{k}+\sum_{i=k+1}^{n} M_{i} f_{k}\right) f_{j} \ddot{\gamma}_{j}+\left(I_{k}+M_{k} C_{k}{ }^{2}+\sum_{i=k+1}^{n} M_{i} f_{k}^{2}\right) \ddot{\gamma}_{k}+\sum_{j=k+1}^{n}\left(M_{j} c_{j}+\sum_{i=j+1}^{n} M_{i} f_{j}\right) f_{k} \ddot{\gamma}_{j} \\
& +\sum_{j=1}^{k-1}\left(l_{k} C_{k}+f_{k} \sum_{i=k+1}^{n} C_{i}\right) f_{j} \dot{\gamma}_{j} / V+\left(l_{k}{ }^{2} C_{k}+B_{k} C_{k}+f_{k}{ }^{2} \sum_{i=k+1}^{n} C_{i}\right) \dot{\gamma}_{k} / V+f_{k} \sum_{j=k+1}^{n}\left(l_{j} C_{j}+f_{j} \sum_{i=j+1}^{n} C_{i}\right) \dot{\gamma}_{j} / V \\
& +l_{k} C_{k} \gamma_{k}+f_{k} \sum_{i=k+1}^{n} C_{i} \gamma_{i}=0
\end{aligned}
$$

ここで,

$$
\begin{aligned}
& A=\sum_{m=1}^{p}\left(l_{0 m}{ }^{2}-l^{2}\right) / p \\
& B_{k}=\sum_{m=1}^{q_{k}}\left(l_{k m}{ }^{2}-l_{k}{ }^{2}\right) / q_{k}
\end{aligned}
$$

\section{付録 4 計算に使用した車両諸元（最大積載状態）}

(1) I 型のトラクタ・ダブルストレーラ（トラクタ・セミトレーラ・セミトレーラ）

$$
\begin{aligned}
& a=1.167 \mathrm{~m}, b=2.333 \mathrm{~m}, C_{1}=2.853 \mathrm{~m}, C_{2}=3.669 \mathrm{~m}, d=1.983 \mathrm{~m}, f_{1}=6.000 \mathrm{~m}, \\
& I=3.500 \mathrm{~m}, l_{1}=5.300 \mathrm{~m}, l_{2}=5.300 \mathrm{~m}, M=6000 \mathrm{~kg}, M_{1}=13000 \mathrm{~kg}, M_{2}=13000 \mathrm{~kg}, \\
& I=19600 \mathrm{kgm}^{2}, I_{1}=68600 \mathrm{kgm}^{2}, I_{2}=58800 \mathrm{kgm}^{2}, \\
& C_{f}=186 \mathrm{kN} / \mathrm{rad}, C_{r}=332 \mathrm{kN} / \mathrm{rad}, C_{1}=405 \mathrm{kN} / \mathrm{rad}, C_{2}=370 \mathrm{kN} / \mathrm{rad}
\end{aligned}
$$


(2) II 型のトラクタ・ダブルストレーラ（トラクタ・セミトレーラ・フルトレーラ）

$a=1.122 \mathrm{~m}, b=2.078 \mathrm{~m}, c_{1}=2.866 \mathrm{~m}, c_{2}=1.800 \mathrm{~m}, c_{3}=2.866 \mathrm{~m}, d=1.778 \mathrm{~m}, f_{1}=6.200 \mathrm{~m}, f_{2}=2.000 \mathrm{~m}$,

$l=3.200 \mathrm{~m}, l_{1}=5.400 \mathrm{~m}, l_{2}=2.000 \mathrm{~m}, l_{3}=5.400 \mathrm{~m}, M=5700 \mathrm{~kg}, M_{1}=13000 \mathrm{~kg}, M_{2}=1000 \mathrm{~kg}, M_{3}=13000 \mathrm{~kg}$,

$I=14700 \mathrm{kgm}^{2}, I_{1}=67200 \mathrm{kgm}^{2}, I_{2}=686 \mathrm{kgm}^{2}, I_{3}=67200 \mathrm{kgm}^{2}$,

$C_{f}=181 \mathrm{kN} / \mathrm{rad}, C_{r}=344 \mathrm{kN} / \mathrm{rad}, C_{1}=333 \mathrm{kN} / \mathrm{rad}, C_{2}=333 \mathrm{kN} / \mathrm{rad}, C_{3}=331 \mathrm{kN} / \mathrm{rad}$

(3) トラクタ・セミトレーラ

$a=2.133 \mathrm{~m}, b=1.867 \mathrm{~m}, c=4.556 \mathrm{~m}, d=1.667 \mathrm{~m}, l=4,000 \mathrm{~m}, l_{1}=8.200 \mathrm{~m}$,

$M=7500 \mathrm{~kg}, M_{1}=27000 \mathrm{~kg}, I=29400 \mathrm{kgm}^{2}, I_{1}=254800 \mathrm{kgm}^{2}$,

$C_{f}=178 \mathrm{kN} / \mathrm{rad}, C_{r}=695 \mathrm{kN} / \mathrm{rad}, C_{1}=687 \mathrm{kN} / \mathrm{rad}$

(4) トラック・フルトレーラ

$a=3.310 \mathrm{~m}, b=1.490 \mathrm{~m}, c_{1}=2.500 \mathrm{~m}, c_{2}=2.059 \mathrm{~m}, d=3.290 \mathrm{~m}, f_{1}=2.500 \mathrm{~m}$,

$l=4.800 \mathrm{~m}, l_{1}=2.500 \mathrm{~m}, l_{2}=3.500 \mathrm{~m}, M=14500 \mathrm{~kg}, M_{1}=1000 \mathrm{~kg}, M_{2}=8500 \mathrm{~kg}$,

$I=78400 \mathrm{kgm}^{2}, I_{1}=588 \mathrm{kgm}^{2}, I_{2}=24500 \mathrm{kgm}^{2}$,

$C_{f}=185 \mathrm{kN} / \mathrm{rad}, C_{r}=385 \mathrm{kN} / \mathrm{rad}, C_{1}=185 \mathrm{kN} / \mathrm{rad}, C_{2}=193 \mathrm{kN} / \mathrm{rad}$

\section{文献}

(1) 青木章, 丸茂喜高, 景山一郎, “多軸・多重連結車両の方向安定性解析”, 日本機械学会論文集 C 編, Vol. 76, No. 771 (2010), pp. 2993-3001.

(2) Mallikajunarao, C. and Fancher, P., "Analysis of the Directional Response Characteristics of Double Tankers", SAE Transactions, SAE Paper 781064, Vol. 87 (1978).

(3) Ervin, R.D. and MacCdam, C.C., "The Dynamic Response of Multiply-Articulated Truck Combinations to Steering Input", SAE Paper 820973 (1982).

(4) Winkler, C.B., Nisonger, R.L. and Ervin, R.D., "Testing the Michigan Double-Bottom Tanker", SAE Transactions, SAE Paper 781066, Vol. 87 (1978).

(5) 斉藤安, 森慎吾, 青木章, “連結車両の操縦性安定性について (第 2 報)”, 自動車技術会学術講演会前刷集 44 年春, 1969, pp. 137-145.

（6）本田英美，“連結車の安全性”，自動車技術，Vol. 25, No. 4, 1971，pp. 442-449.

(7) 青木章, 丸茂喜高, 景山一郎, “多重連結車両の方向安定性と操縦性に関する基本特性”, 日本機械学会論文集 C 編，Vol. 75, No. 760 (2009), pp. 3152-3159. 